\title{
Prophylactic nesiritide does not prevent dialysis or all-cause mortality in patients undergoing high-risk cardiac surgery
}

\author{
A. Ahsan Ejaz, MD, ${ }^{\mathrm{a}}$ Tomas D. Martin, MD, ${ }^{\mathrm{b}}$ Richard J. Johnson, MD, ${ }^{\mathrm{a}, \mathrm{d}}$ Almut G. Winterstein, PhD, ${ }^{\mathrm{c}}$ \\ Charles T. Klodell, MD, ${ }^{\mathrm{b}}$ Philip J. Hess, Jr, MD, ${ }^{\mathrm{b}}$ Ayad K. Ali, PharmD, ${ }^{\mathrm{c}}$ Elaine M. Whidden, ARNP, ${ }^{\mathrm{a}}$ \\ Nancy L. Staples, RN, ${ }^{\mathrm{b}}$ James A. Alexander, MD, ${ }^{\mathrm{d}}$ Mary Ann House-Fancher, ARNP, ${ }^{\mathrm{b}}$ and \\ Thomas M. Beaver, MD, MPH
}

\begin{abstract}
Objectives: Natriuretic peptides have been shown to improve renal blood flow and stimulate natriuresis. In a recent retrospective trial, we documented that prophylactic use of nesiritide was associated with a $66 \%$ reduction in the odds for dialysis or in-hospital mortality at 21 days in patients undergoing high-risk cardiac surgery; therefore, we designed a prospective trial.
\end{abstract}

\begin{abstract}
Methods: This prospective, randomized, clinical trial included 94 patients undergoing high-risk cardiac surgery comparing a 5-day course of continuous nesiritide (at a dose of $0.01 \mu \mathrm{g} \cdot \mathrm{kg}^{-1} \cdot \mathrm{min}^{-1}$ started before surgery) versus placebo. The primary end point was dialysis and/or all-cause mortality within 21 days; secondary end points were incidence of acute kidney injury, renal function, and length of stay.
\end{abstract}

\begin{abstract}
Results: Nesiritide did not reduce the primary end point of incidence of dialysis and/or all-cause mortality through day $21(6.6 \%$ vs $6.1 \% ; P=.914)$. Fewer patients receiving nesiritide had acute kidney injury (defined as an absolute increase in serum creatinine $\geq 0.3 \mathrm{mg} / \mathrm{dL}$ from baseline or a percentage increase in serum creatinine $\geq 50 \%$ from baseline within 48 hours) compared with controls $(2.2 \%$ vs $22.4 \% ; P=.004)$, and mean serum creatinine was lower in the immediate postoperative period in the nesiritide group $(1.18 \pm 0.41 \mathrm{mg} / \mathrm{dL}$ vs 1.45 $\pm 0.74 \mathrm{mg} / \mathrm{dL} ; P=.028$ ). However, no difference in length of stay was noted (nesiritide $20.73 \pm 3.05$ days vs control $21.26 \pm 4.03$ days; $P=.917$ ).
\end{abstract}

Conclusions: These results do not demonstrate a benefit for prophylactic use of nesiritide on the incidence of dialysis and/or death in patients undergoing high-risk cardiac surgery. Although nesiritide may provide some renal protection in the immediate postoperative period, no effect on length of stay was observed.

Acute kidney injury (AKI) is a major complication of the more than 200,000 cardiovascular operations performed on adult Americans annually. ${ }^{1}$ The incidence of AKI after cardiac surgery is generally low $(1 \%-2 \%)^{2}$ but is much higher in patients with thoracic aortic aneurysm and cardiac valve operations (AKI: $25 \%-40 \%$; perioperative mortality: $8 \%-10 \%)^{3,4}$ When thoracic aortic aneurysm surgery is complicated by AKI requiring renal replacement therapy (RRT), the mortality rate rises to $50 \% .^{5}$ There are very few effective interventional studies in this group of patients.

\footnotetext{
From the Division of Nephrology, Hypertension and Transplantation, ${ }^{a}$ Division of Thoracic and Cardiothoracic Surgery, ${ }^{\mathrm{b}}$ and Department of Pharmaceutical Outcomes and Policy, ${ }^{\mathrm{c}}$ University of Florida, Gainesville, Fla; and Renal Diseases and Hypertension, ${ }^{\mathrm{d}}$ University of Colorado Health Sciences Center, Denver, Colo.

Disclosures: The study was conducted under an investigator-proposed research grant from Scios, Inc. The authors do not have any other conflict of interest.

Clinical trials registration: ClinicalTrials.gov NCT00110201.

Received for publication Sept 15, 2008; revisions received Feb 16, 2009; accepted for publication May 15, 2009; available ahead of print July 6, 2009.

Address for reprints: A. Ahsan Ejaz, MD, Division of Nephrology, Hypertension and Transplantation, University of Florida, PO Box 100224, Gainesville, FL 326100224 (E-mail: ejazaa@medicine.ufl.edu).

J Thorac Cardiovasc Surg 2009;138:959-64

$0022-5223 / \$ 36.00$

Copyright (C) 2009 by The American Association for Thoracic Surgery

doi:10.1016/j.jtcvs.2009.05.014
}

Natriuretic peptides are attractive agents to consider for renoprotection owing to their ability to cause renal vasodilation, stimulation of natriuresis, and preservation of glomerular filtration rate (GFR). However, the literature on the effectiveness of natriuretic peptides in the prevention of AKI remains controversial. ${ }^{6}$ In a large observational study $(n=940)$ to evaluate the clinical effectiveness of natriuretic peptides in the prevention of AKI after cardiovascular surgery, $\mathrm{we}^{7}$ demonstrated a $66 \%$ reduction in the odds for dialysis or in-hospital mortality at 21 days in subjects whose baseline serum creatinine ( $\mathrm{SCr}$ ) value was less than $1 \mathrm{mg} / \mathrm{dL}$. Because this latter study was retrospective, we proceeded with a prospective, double-blind study to evaluate the effect of nesiritide on renal tissue injury, renal function, and requirement for RRT and/or all-cause mortality in patients undergoing high-risk cardiac surgery.

\section{METHODS}

The study is a prospective, double-blind, placebo-controlled, randomized clinical trial conducted by the nephrology and cardiovascular surgery teams at Shands Hospital at the University of Florida in Gainesville. The study was approved by the Western Institutional Review Board, registered at the National Institutes of Health'sClinicalTrials.gov (NCT00110201) Web site, and was funded by an investigator-proposed grant from Scios, Inc. 


\begin{tabular}{|c|c|}
\hline \multicolumn{2}{|c|}{ Abbreviations and Acronyms } \\
\hline AKI & $=$ acute kidney injury \\
\hline $\mathrm{AKI}_{0.3 \mathrm{mg} / \mathrm{dI}}$ & $\begin{aligned}= & \text { absolute increase in serum creatinine } \\
& \text { of more than or equal to } 0.3 \mathrm{mg} / \mathrm{dL} \\
& \text { from baseline }\end{aligned}$ \\
\hline $\mathrm{AKI}_{50 \%}$ & $\begin{array}{l}=\text { increase in serum creatinine of more } \\
\text { than or equal to } 50 \% \text { from } \\
\text { baseline within } 48 \text { hours }\end{array}$ \\
\hline $\mathrm{CI}$ & $=$ confidence interval \\
\hline GFR & $=$ glomerular filtration rate \\
\hline MDRD & $\begin{aligned}= & \text { Modification of Diet in Renal } \\
& \text { Disease }\end{aligned}$ \\
\hline OR & $=$ odds ratio \\
\hline RRT & $=$ renal replacement therapy \\
\hline $\mathrm{SCr}$ & $=$ serum creatinine \\
\hline
\end{tabular}

\section{Participants}

Initially, patients undergoing surgery for thoracic aortic aneurysm who were older than 18 years of age and had an $\mathrm{SCr}$ value greater than $1 \mathrm{mg} /$ $\mathrm{dL}$ but less than $2 \mathrm{mg} / \mathrm{dL}$ were deemed to be at high risk per review of the literature ${ }^{2}$ and were eligible for the study. Because of low enrollment, after the first 2 patients were enrolled the inclusion criteria were modified to include patients with cardiac valve surgery, and the $\mathrm{SCr}$ criterion was replaced with estimated GFR (using the short version of the Modification of Diet in Renal Disease [MDRD] GFR calculator) between 30 and $90 \mathrm{~mL}$. $\min ^{-1} \cdot 1.73 \mathrm{~m}^{2-1}$ to better reflect renal function. Patients with a history of adverse reaction to nesiritide, organ transplant, preoperative intra-aortic balloon pump, or symptomatic, acute decompensated congestive heart failure were excluded.

\section{Study Protocol}

Eligible patients were randomized according to race, gender, and diabetes status to receive a 5-day course of continuous nesiritide (at a dose of 0.01 $\mu \mathrm{g} \cdot \mathrm{kg}^{-1} \cdot \mathrm{min}^{-1}$ ) or an identical appearing placebo, starting in the operating room immediately before the operation. Study drugs were titrated to a maximum of $0.03 \mu \mathrm{g} \cdot \mathrm{kg}^{-1} \cdot \mathrm{min}^{-1}$ over a 4-hour period to maintain postoperative urine output greater than $1 \mathrm{~mL} \cdot \mathrm{kg}^{-1} \cdot \mathrm{h}^{-1}$. Patients who did not achieve target urine output after the maximum dose of study drug or placebo could then receive 1 to $5 \mathrm{mg}$ bumetanide bolus intravenously, followed by bumetanide continuous infusion as required. All patients received routine postoperative supportive care for their medical and surgical problems, including care for AKI, optimization of fluid and nutritional status, inotropic support, and adjustment of doses of medication as appropriate for patients with renal dysfunction. The need for RRT was determined independently by the patient's treating nephrologists per current standard of care criterion, which included blood urea nitrogen greater than $80 \mathrm{mg} / \mathrm{dL}$, electrolyte or acid-base disorders not responding to medical management, and diuretic unresponsiveness with urine output less than $0.5 \mathrm{mg} \cdot \mathrm{kg}^{-1} \cdot \mathrm{h}^{-1}$ and refractory volume overload as defined by central venous pressures greater than $15 \mathrm{~mm}$ Hg. Postoperative GFR was calculated using the MDRD GFR calculator and is in accordance with previous published reports. ${ }^{8,9}$

\section{Outcomes}

The primary end point of the study was the incidence of dialysis and/or all-cause mortality through day 21 . The predetermined secondary end points included the incidence of $\mathrm{AKI}$, mean $\mathrm{SCr}$, peak $\mathrm{SCr}$, change from baseline to peak SCr, peak blood urea nitrogen, end of hospital stay, or study day 21; mean urine output per day by day 5 ; and length of hospital stay. AKI is de- fined as an absolute increase in SCr of more than or equal to $0.3 \mathrm{mg} / \mathrm{dL}$ from baseline $\left(\mathrm{AKI}_{0.3 \mathrm{mg} / \mathrm{dL}}\right)$ or an increase in $\mathrm{SCr}$ of more than or equal to $50 \%$ from baseline within 48 hours $\left(\mathrm{AKI}_{50 \%}\right.$ ) after surgery in accordance with the Acute Kidney Injury Network's criteria. ${ }^{10}$ Post hoc analyses included the percent change in postoperative GFR relative to baseline.

\section{Sample Size and Randomization}

The sample size was calculated on the basis of a retrospective study that examined the University of Florida experience with nesiritide in patients undergoing cardiac surgery ${ }^{7}$ and had an $80 \%$ power to declare efficacy or harm. The study plan was based on rates of composite end points of $20 \%$ (placebo) versus $5 \%$ (nesiritide). The targeted population for the trial had an observed odds ratio $(\mathrm{OR})$ of 0.21 , similar to that reported in the retrospective study $(\mathrm{OR}$ $0.19) .{ }^{7}$ Up to a total of 164 (was 124) patients undergoing thoracic aortic aneurysm surgery were to be enrolled and randomized to receive nesiritide or an identical appearing placebo drug. Randomization was performed by the Investigational Drug Program housed in Pharmacy at the Shands Hospital. The study was conducted as a 2 -stage group sequential design with 92 patients assigned to stage I ( 46 patients per arm) and 72 patients assigned to stage II (36 additional patients per arm). The following inferential rule was used: (1) If the Z-test for proportions (pooled standard deviation) in stage I falls above 2.28 in absolute value, halt the study and declare efficacy/harm. If this Z-test in stage I falls below 1.08 in absolute value, halt the study and declare futility. If the Ztest in absolute value at stage I falls between 1.08 and 2.28, continue to stage II. (2) If after stage II the $\mathrm{Z}$-value (pooled standard deviation) exceeds 2.00 in absolute value, declare efficacy/harm. Otherwise, declare no significant difference. If there is indeed no advantage for the drug in the true target population, there is a $5 \%$ probability of falsely declaring efficacy or harm (type I error). On the basis of a pilot study, the estimated incidence in the aneurysm/valve stratum in the cohort study was $4.4 \%$ for nesiritide versus $18.7 \%$ for no nesiritide. If the true failure rates are $5 \%$ for the drug and $20 \%$ for the placebo, the study has an $80 \%$ power to declare efficacy. Other end points will be studied using the Z-test for proportions or $t$ tests for quantitative end points, but the study is powered strictly on the basis of the primary combined end point. This design is minimax in the sense that no 2-stage design with $80 \%$ power at $P<.05$ has a smaller maximum expected sample size. The worst-case scenario is an average sample size of 126 patients, which occurs when the actual target population difference is $11 \%$, rather than $0 \%$ (null hypothesis) or 15\% (alternate hypothesis). A single stage study would have required 146 patients. The primary analysis is by intent-to-treat.

Patients were enrolled from the cardiothoracic surgery service at the University of Florida. Informed consent was obtained for all patients. Random allocation sequences were generated by block stratification by the institutional investigational drug services and concealed until the study was completed. The study participants, physicians, nurses, and data analysis teams were blinded to group assignment.

\section{Statistical Methods}

Demographic characteristics, perioperative variables, and outcomes were compared by univariate and multivariate analyses. The change from baseline to postoperative peak SCr was compared by an analysis of covariance model, with treatment group as qualitative factor and baseline $\mathrm{SCr}$ value as covariate, as well as using nonparametric tests. Data are presented as mean \pm standard error of mean. Univariate comparisons of the presence of risk factors were computed by $\chi^{2}$ and unpaired $t$ tests for categorical and continuous variables, respectively.

\section{Study Design, Data Safety, Analysis, and Manuscript Preparation}

The study conception, design, execution, data collection, analysis, and manuscript preparation were performed in their entirety and independently by the investigators. The Data Safety Monitoring Board provided appropriate oversight and monitoring of the conduct of the clinical trial to ensure the safety of participants and the validity and integrity of the data. 


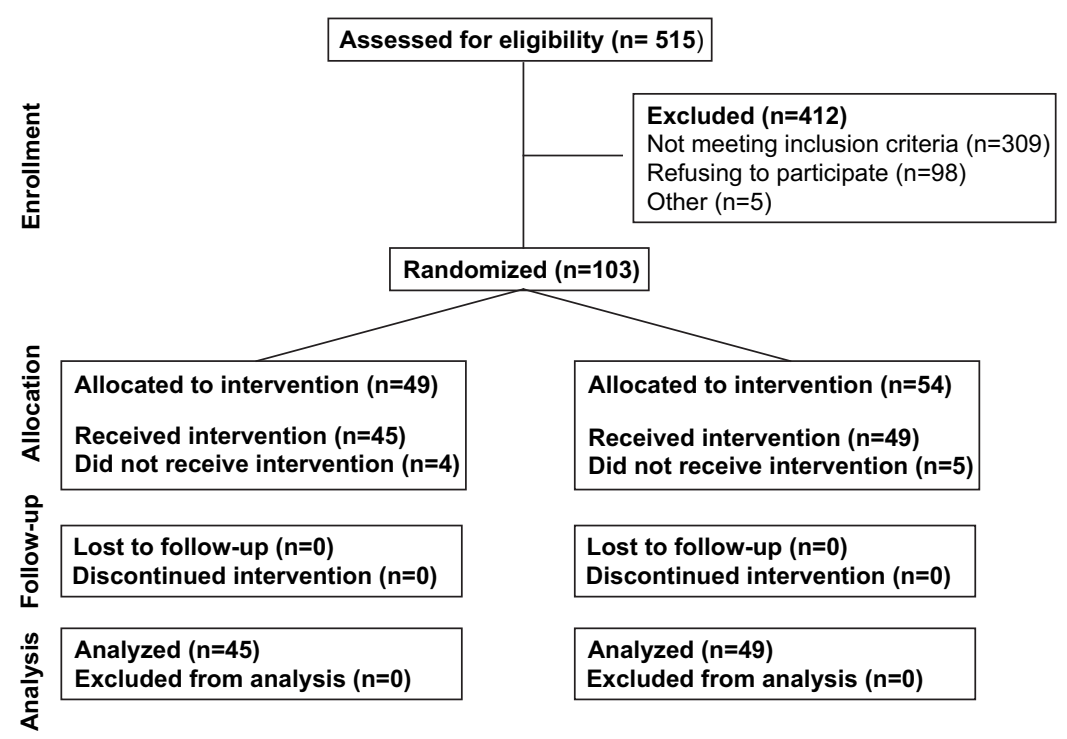

FIGURE 1. Flow of participants.

\section{RESULTS}

In accordance with the a priori determination, the study was stopped after completion of stage I inasmuch as the Ztest was below 1.08 in absolute value. Importantly, the primary event rate was low in both groups (nesiritide 3/45 [6.6\%] vs control $3 / 49[6.1 \%])$, and it was determined that statistical significance for a definitive result could not be achieved during the second stage of the study.

\section{Patient Enrollment}

The number of subjects screened, enrolled, and dropped out are shown in Figure 1. One hundred three patients completed enrollment but 9 withdrew consent. The remaining 94 patients constituted the study cohort.

\section{Baseline Characteristics}

Mean age of the study population was $65.1 \pm 12$ years, $66 \%$ of the patients were male, and $92.5 \%$ were white. Mean preoperative $\mathrm{SCr}$ was $1.17 \pm 0.29 \mathrm{mg} / \mathrm{dL}$ with a calculated MDRD GFR of $63.7 \pm 16.3 .4 \mathrm{~mL} \cdot \mathrm{min}^{-1} \cdot 1.73 \mathrm{~m}^{2-1}$; and left ventricular ejection fraction was $49.4 \% \pm 9.4 \%$ ( $=89$ ); comorbidities are presented in Table 1 . There was no significant difference between the 2 study groups with respect to baseline demographic and clinical characteristics (Table 1). Most patients (76.6\%) underwent thoracic aortic aneurysm surgery (ascending aortic and arch replacement, $57.5 \%$; descending aortic replacement, $19.1 \%$; valve only, $23.4 \%$ ). Differences in duration of surgery (nesiritide $424.66 \pm 16.26$ minutes vs control $383.69 \pm 14.65$ minutes; $P=.065$ ), duration of cardiopulmonary bypass support (nesiritide $177.14 \pm 11.42$ minutes vs control $158.41 \pm 9.29$ minutes; $P=.207$ ), and aortic crossclamp time (nesiritide $109.70 \pm 7.97$ minutes vs control $106.66 \pm 7.02$ minutes; $P=.776)$ were not significant between the groups. Statisti- cally significant differences were also not observed with regard to the number of patients who underwent circulatory arrest (nesiritide $53.3 \%$ vs control $42.9 \% ; P=.302$; circulatory arrest time: nesiritide $20.77 \pm 2.90$ minutes vs 14.90 \pm 2.16 minutes; $P=.113$ ), thoractomy (nesiritide $31.1 \%$ vs control $30.6 \% ; P=1.000$ ), and midline sternotomy (nesiritide $68.9 \%$ vs control $69.4 \% ; P=1.000$ ) between the groups.

\section{Primary Outcome}

There was no statistically significant difference between the groups with regard to the incidence of dialysis and/or all-cause mortality through day 21 (nesiritide 3/45 [6.6\%]; control 3/49 [6.1\%]; $P=.914$ ) (Figure 2). In the nesiritide group, 1 patient died on the second postoperative day of complications of cardiovascular surgery unrelated to the study drug (as assessed by the Data Safety Monitoring Board) and 2 patients required continuous RRT. In the control group, 2 patients required hemodialysis and 1 patient received treatment with continuous RRT. RRT was indicated in the nesiritide group primarily for volume overload and decreased urine output (preceding 24-hour urine output: nesiritide $1168.33 \pm 1050.44 \mathrm{~mL}$ vs control $4228.66 \pm 502.93$ $\mathrm{mL}$ in patients who underwent dialysis; $P=.020$ ), whereas the indication in the control group was primarily for worsening renal function ( $\mathrm{SCr}$ : nesiritide $1.83 \pm 0.15 \mathrm{mg} / \mathrm{dL}$ vs control $5.03 \pm 0.55 \mathrm{mg} / \mathrm{dL}[P=.023]$ in the nesiritide and control patients undergoing dialysis, respectively). Patient demographics and clinical characteristics were otherwise not statistically different between the groups.

\section{Secondary Outcomes}

$\mathrm{AKI}_{50 \%}$ developed in fewer patients receiving nesiritide than in the control group (nesiritide $2.2 \%$ [1/45] vs control 
TABLE 1. Baseline patient characteristics

\begin{tabular}{|c|c|c|c|}
\hline Variable & $\begin{array}{l}\text { Nesiritide } \\
(\mathrm{n}=45)\end{array}$ & $\begin{array}{l}\text { Control } \\
(n=49)\end{array}$ & $\begin{array}{c}P \\
\text { value }\end{array}$ \\
\hline \multicolumn{4}{|l|}{ Demographics } \\
\hline Age (y) & $64.1 \pm 13.31$ & $65.91 \pm 10.76$ & .484 \\
\hline Sex $(\%$ male $)$ & 64.4 & 67.3 & .820 \\
\hline \multicolumn{4}{|l|}{ Race $(\%)$} \\
\hline White & 88.9 & 96 & .147 \\
\hline African American & 8.9 & 2 & .190 \\
\hline Other & 2.2 & 2 & 1.000 \\
\hline \multicolumn{4}{|l|}{ Surgery type $(\%)$} \\
\hline TAA & 82.2 & 71.4 & .235 \\
\hline Valves & 17.8 & 28.6 & .217 \\
\hline \multicolumn{4}{|l|}{ Comorbid conditions $(\%)$} \\
\hline Hypertension & 68.9 & 63.3 & .666 \\
\hline CAD & 33.3 & 40.8 & .524 \\
\hline Previous CV surgery & 26.6 & 32.6 & .652 \\
\hline Diabetes & 17.8 & 12.2 & .566 \\
\hline CVA & 13.3 & 4.4 & .147 \\
\hline PVD & 11.1 & 4.1 & .254 \\
\hline \multicolumn{4}{|l|}{ Renal function } \\
\hline $\mathrm{SCr}(\mathrm{mg} / \mathrm{dL})$ & $1.16 \pm 0.29$ & $1.18 \pm 0.30$ & .702 \\
\hline $\begin{array}{l}\text { MDRD GFR }\left(\mathrm{mL} \cdot \mathrm{min}^{-1}\right. \\
\left.\quad\left[1.73 \mathrm{~m}^{2}\right]^{-1}\right)\end{array}$ & $64.4 \pm 16.73$ & $63.12 \pm 17.07$ & .693 \\
\hline BUN (mg/dL) & $22.17 \pm 14.35$ & $19.80 \pm 8.16$ & .356 \\
\hline \multicolumn{4}{|l|}{ Cardiac function } \\
\hline LVEF $(\%)$ & $48.56 \pm 1.29$ & $50.27 \pm 1.52$ & .394 \\
\hline NYHA class I $(\%)$ & 93.3 & 89.7 & .339 \\
\hline $\begin{array}{l}\text { Mean arterial } \\
\text { pressure }(\mathrm{mm} \mathrm{Hg})\end{array}$ & $89.31 \pm 12.74$ & $92.94 \pm 13.22$ & .178 \\
\hline $\begin{array}{l}\text { Cleveland Clinic } \\
\text { Scoring System }\end{array}$ & $3.40 \pm 0.22$ & $3.51 \pm 0.23$ & .735 \\
\hline
\end{tabular}

$T A A$, Thoracic aortic aneurysm; $C A D$, coronary artery disease; $C V$, cardiovascular; $C V A$, cerebrovascular accident; $P V D$, peripheral vascular disease; $S C r$, serum creatinine; $B U N$, blood urea nitrogen; $L V E F$, left ventricular ejection fraction; NYHA, New York Heart Association.

$22.4 \%$ [11/49]; $P=.004)$. Similar results were observed when a different criterion for $\mathrm{AKI}$ was applied: $\mathrm{AKI}_{0.3 \mathrm{mg} / \mathrm{dL}}$ developed in fewer patients receiving nesiritide than in the control group (nesiritide 6.6\% [3/45] vs control $28.5 \%$ [14/49]: $P=.007$, OR 5.6, 95\% CI [CI] 1.4-21) (Figure 3). The difference in AKI was observed in patients with $\mathrm{SCr}$ greater than $1.2 \mathrm{mg} / \mathrm{dL}$ (nesiritide $7.1 \%$ [1/14] vs control $43.7 \%$ [7/16]; $P=.030$, OR $10.1,95 \%$ CI $1.11-97)$ and in those who underwent thoracic aortic aneurysm surgery (nesiritide $2.7 \%$ [1/37] vs control 25.7\% [9/35]; $P=$ .006 , OR $12.4,95 \%$ CI 1.4-104.5).

The 5-day cumulative urine output (nesiritide $8.6 \pm 7.3 \mathrm{~L}$ vs control $14.9 \pm 2.9 \mathrm{~L} ; P=.269$ ) was not different between groups. The frequency of administration of standard doses of diuretics was also not different (nesiritide $1.11 \pm 0.21 \mathrm{vs}$ control $1.28 \pm 0.23$ ); half of the study participants did not receive any diuretics (nesiritide 23/45 vs control 24/49; $P=.807$ ) in the first 5 postoperative days.

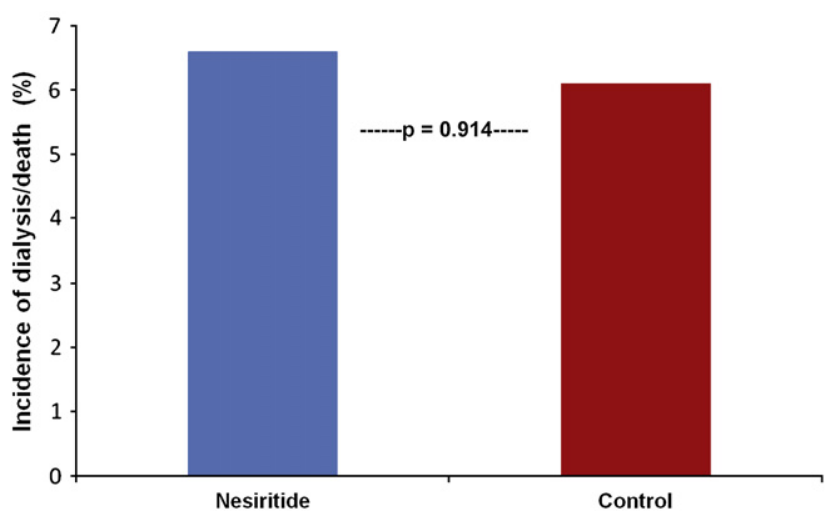

FIGURE 2. Incidence of primary events.

Length of hospital stay (nesiritide $20.73 \pm 3.05$ days vs control $21.26 \pm 4.03$ days; $P=.917$ ) was not significantly different between the groups. However, in the subset of patients who did have AKI $(n=17)$, those receiving nesiritide had shortened hospital stay (nesiritide $22.28 \pm 4.20$ days vs control $33 \pm 20.51$ days; $P=.017$ ) compared with the control group.

\section{Post Hoc Analyses}

By post hoc analyses, fewer patients in the nesiritide group sustained severe kidney injury (defined as a rise in $\mathrm{SCr}$ of $1 \mathrm{mg} / \mathrm{dL}$ or more) compared with patients in the control group (nesiritide 1 vs control $11 ; P=.004$ ). Postoperative GFR relative to baseline also increased in the nesiritide group whereas it decreased in the control group $(1.76 \% \pm$ $4.1 \%$ vs $-11.68 \% \pm 4.21 \% ; P=.026$ ) (Figure 4 .). The differences were more pronounced when analyses were restricted to patients with baseline GFR less than $45 \mathrm{~mL}$. $\min ^{-1} \cdot\left(1.73 \mathrm{~m}^{2}\right)^{-1}(-2.24 \% \pm 13.41 \%$ vs $-33.17 \% \pm$ $8.03 \% ; P=.075 ; \mathrm{n}=13)$. In patients with the largest decrease in postoperative GFR $(\geq 30 \% ; n=21)$, the use of nesiritide was associated with a statistically significant decrease in the incidence of $\mathrm{AKI}_{50 \%}(22.2 \%$ [2/9] vs $91.6 \%$ [11/12]; $P=.002)$.

\section{Side Effects: Hypotension and Nesiritide}

Nesiritide has been associated with hypotension, especially if given by bolus. ${ }^{6}$ In this trial, episodes of hypotension solely related to the administration of nesiritide were not recognized, in part because of the frequent concomitant requirement for vasopressors in many of the patients. However, the number of vasopressors administered was higher in the nesiritide group $(P=.023)$. Significant differences in absolute change in mean arterial pressures between the groups were not evident through day $5(P=.858, .359, .914, .492$, and .930 , days $1-5$, respectively). Usage of diuretics did not differ among the groups. 

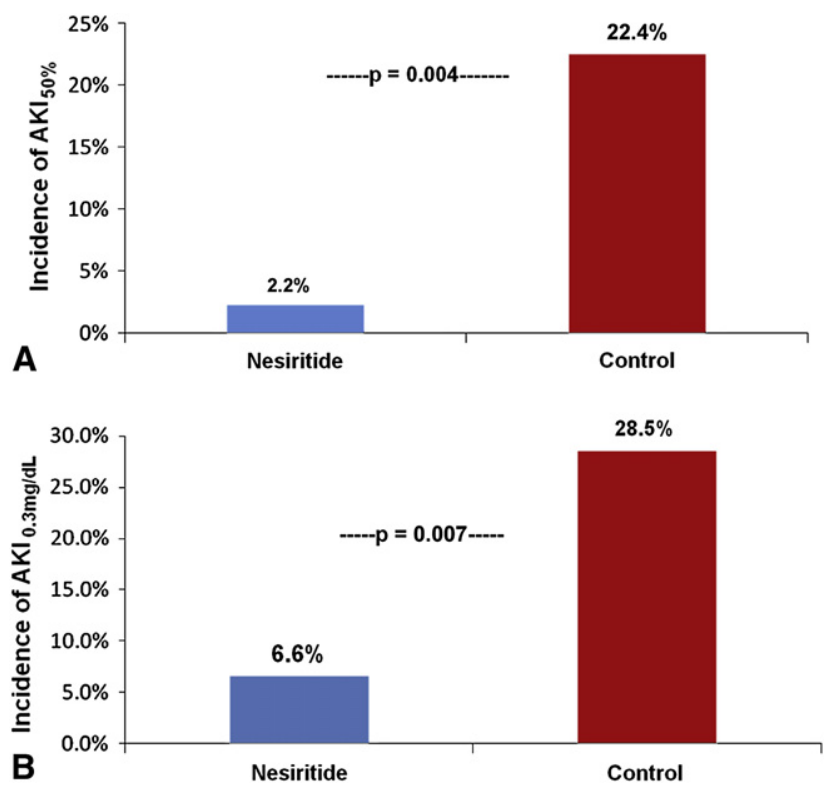

FIGURE 3. Incidence of acute kidney injury (AKI) using different definitions.

\section{DISCUSSION}

AKI is a serious complication of cardiovascular surgery and is associated with markedly increased rates of mortality and morbidity. ${ }^{11-13}$ The pathogenesis of postoperative AKI is complex but is thought to be mediated by a reduction in renal blood flow associated with persistent renal vasoconstriction, mediated in part by the release of proinflammatory and vasoconstrictive mediators. ${ }^{14}$ Although a variety of trials with different renal vasodilators have been negative, ${ }^{15-18}$ there has been recent interest in the use of natriuretic peptides owing to their ability to cause afferent renal vasodilation, improve GFR, and antagonize the proinflammatory effects of a variety of cytokines. ${ }^{19,20}$ Indeed, in a recent uncontrolled retrospective trial, our group ${ }^{7}$ reported a remarkable $80 \%$ decrease in AKI in subjects undergoing aortic aneurysm therapy that received nesiritide therapy. Other groups have also reported a reduction in AKI using either atrial natriuretic peptide or brain natriuretic peptide after cardiovascular surgery. ${ }^{8,21,22}$ This led us to do a prospective, double-blind, controlled trial to determine whether nesiritide could provide renal protection in subjects undergoing cardiovascular surgery.

The design of the study was based on selecting subjects at high risk for the development of AKI. We therefore studied subjects undergoing aortic aneurysm surgery and/or subjects having valve replacement with or without coronary artery bypass in whom higher rates of AKI $(4 \%-16 \%)$ can be predicted. Furthermore, we also identified subjects with modest (GFR $30-90 \mathrm{~mL} \cdot \min ^{-1} \cdot\left[1.73 \mathrm{~m}^{2}\right]^{-1}$ ) but not severe chronic kidney disease, inasmuch as our retrospective study suggested that this is the group most likely to benefit
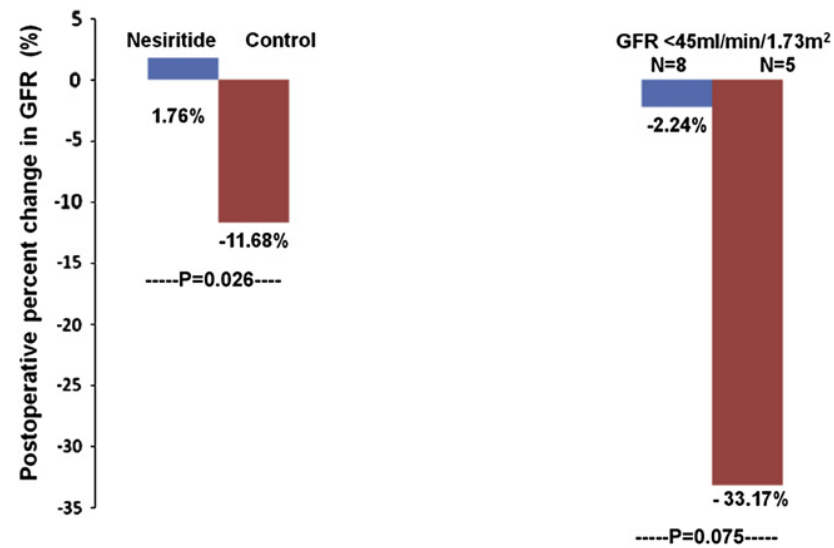

FIGURE 4. Percent change in postoperative glomerular filtration rate $(G F R)$ compared with baseline.

from nesiritide prophylaxis. Furthermore, inasmuch as a nesiritide bolus can induce hypotension (reviewed in reference 6), we opted to initiate nesiritide as a continuous infusion (without bolus administration) for 5 days beginning immediately before surgery in the operating room. Although no hypotension attributable to nesiritide was noted, subjects randomized to nesiritide were administered pressors more frequently.

The major finding in this study was that the primary end point, defined as dialysis or death, was not different between groups. Importantly, there was no favorable effect of randomization to nesiritide with regard to the incidence of dialysis and/or all-cause mortality through day 21 . One problem was that fewer patients reached this end point ( 3 subjects per group) than anticipated, and that indeed contributed to the futility. This did not differ even when the data were analyzed with a different criterion (need for dialysis defined as $\mathrm{SCr} \geq$ $4.5 \mathrm{mg} / \mathrm{dL}$ ) that was used in a study that reported improved dialysis-free survival with natriuretic peptides (nesiritide 4/ $45 \mathrm{vs} 4 / 49 ; P=1.00) .{ }^{21}$ It was of interest that AKI necessitating RRT developed in all 3 control patients whereas the 2 nesiritide-treated subjects received RRT for clinical evidence of volume overload. Nevertheless, these numbers are too small to make any definitive statements related to potential differences in reasons that patients achieved the primary outcome.

In terms of secondary end points, there was no difference in hospital length of stay in either group. However, we did observe some evidence for renoprotection as noted by reduced AKI in the nesiritide group versus the placebo group. It is possible that this may represent the known effect of natriuretic peptides to cause renal vasodilation, and hence that the effect on renal function simply reflects a transient hemodynamic effect. Although this remains a possibility, the use of other renal vasodilators, such as dopamine and fenoldopam, was not associated with any benefit in renal function in the acute postoperative period. ${ }^{16,17}$ 
Post hoc analyses suggested that nesiritide may provide greater renoprotection in subjects with baseline renal insufficiency (estimated GFR $<45 \mathrm{~mL} \cdot \mathrm{min}^{-1} \cdot\left[1.73 \mathrm{~m}^{2}\right]^{-1}$ ). Future studies may be indicated to determine whether targeting this specific population could result in different outcomes. Until this is shown in multicenter randomized trials, we do not recommend the routine use of nesiritide for the prophylaxis of patients undergoing cardiovascular surgery.

The investigators acknowledge the active support of DSMB members Abraham Hartzema, PharmD, MSPH, PhD, Meenakshi Devidas, PhD, Edward A. Ross, MD, Daniel F. Pauly, MD, PhD, and study coordinators Allan Finlay, RN, Michelle Armstrong, RN, Karissa Roberts, Mary Alice Dennis, RN, and Michelle Hunter during the course of the study.

\section{References}

1. Society of Thoracic Surgeons. Fall 2007 Report-Adult Cardiac Database Executive Summary: www.sts.org. http://www.sts.org/sections/stsnationaldatabase/ publications/executive/article.html.

2. Chertow GM, Levy EM, Hammermeister KE, Grover F, Daley J. Independent association between acute renal failure and mortality following cardiac surgery. $\mathrm{Am}$ J Med. 1998;104:343-8.

3. Cina CS, Lagana A, Bruin G, Ricci C, Doobay B, Tittley J, et al. Thoracoabdominal aortic aneurysm repair: a prospective cohort study of 121 cases. Ann Vasc Surg. 2002;16:631-8.

4. Godet G, Fleron MH, Vicaut E, Zubicki A, Bertrand M, Riou B, et al. Risk factors for acute postoperative renal failure in thoracic or thoracoabdominal aortic surgery: a prospective study. Anesth Analg. 1997;85:1227-32.

5. Safi HJ, Harlin SA, Miller CC, Iliopoulos DC, Joshi A, Mohasci TG, et al. Predictive factors for acute renal failure in thoracic and thoracoabdominal aortic aneurysm surgery. J Vasc Surg. 1996;24:338-44.

6. Ejaz AA, Heinig ME, Kazory A, Bihorac A, Hobson CE, Beaver TM. The rise and fall of natriuretic peptides in acute kidney injury: a misunderstood relationship? Rev Cardiovasc Med. 2007;8:S32-7.

7. Beaver TM, Winterstein AG, Shuster JJ, Gerhard T, Martin T, Alexander JA, et al. Effectiveness of nesiritide on dialysis or all-cause mortality in patients undergoing cardiothoracic surgery. Clin Cardiol. 2006;29:18-24.

8. Mentzer RM Jr, Oz MC, Sladen RN, Graeve AH, Hebeler RF Jr, Luber JM Jr, et al. NAPA Investigators. Effects of perioperative nesiritide in patients with left ventricular dysfunction undergoing cardiac surgery: the NAPA Trial. $J$ Am Coll Cardiol. 2007;49:716-26.

9. Cooper WA, O'Brien SM, Thourani VH, Guyton RA, Bridges CR, Szczech LA, et al. Impact of renal dysfunction on outcomes of coronary artery bypass surgery: results from the Society of Thoracic Surgeons National Adult Cardiac Database. Circulation. 2006;113:1063-70.

10. Mehta RL, Kellum JA, Shah SV, Molitoris BA, Ronco C, Warnock DG, et al. Acute Kidney Injury Network. Acute Kidney Injury Network: report of an initiative to improve outcomes in acute kidney injury. Crit Care. 2007;11:R31.

11. Bove T, Calabrò MG, Landoni G, Aletti G, Marino G, Crescenzi G, et al. The incidence and risk of acute renal failure after cardiac surgery. J Cardiothorac Vasc Anesth. 2004; 18:442-5.

12. Van Den Noortgate N, Mouton V, Lamot C, Van Nooten G, Dhondt A, Vanholder R, et al. Outcome in a post-cardiac surgery population with acute renal failure requiring dialysis: does age make a difference? Nephrol Dial Transplant. 2003; 18:732-6.

13. Ostermann ME, Taube D, Morgan CJ, Evans TW. Acute renal failure following cardiopulmonary bypass: a changing picture. Intensive Care Med. 2000;26:565-71.

14. Devarajan P. Update on mechanisms of ischemic acute kidney injury. J Am Soc Nephrol. 2006;17:1503-20.

15. Tumlin JA, Finkel KW, Murray PT, Samuels J, Cotsonis G, Shaw AD. Fenoldopam mesylate in early acute tubular necrosis: a randomized, double-blind, placebo-controlled clinical trial. Am J Kidney Dis. 2005;46:26-34.

16. Bove T, Landoni G, Calabrò MG, Aletti G, Marino G, Cerchierini E, et al. Renoprotective action of fenoldopam in high-risk patients undergoing cardiac surgery: a prospective, double-blind, randomized clinical trial. Circulation. 2005;111: 3230-5.

17. Lauschke A, Teichgräber UK, Frei U, Eckardt KU. "Low-dose" dopamine worsens renal perfusion in patients with acute renal failure. Kidney Int. 2006; 69:1669-74.

18. Lassnigg A, Donner E, Grubhofer G, Presterl E, Druml W, Hiesmayr M. Lack of renoprotective effects of dopamine and furosemide during cardiac surgery. $J$ Am Soc Nephrol. 2000;11:97-104.

19. Lanese DM, Yuan BH, Falk SA, Conger JD. Effects of atriopeptin III on isolated rat afferent and efferent arterioles. Am J Physiol. 1991;261:F1102-9.

20. Houben AJ, van der Zander K, de Leeuw PW. Vascular and renal actions of brain natriuretic peptide in man: physiology and pharmacology. Fundam Clin Pharmacol. 2005; 19:411-9.

21. Swärd K, Valsson F, Odencrants P, Samuelsson O, Ricksten SE. Recombinant human atrial natriuretic peptide in ischemic acute renal failure: a randomized placebo-controlled trial. Crit Care Med. 2004;32:1310-5.

22. Chen HH, Sundt TM, Cook DJ, Heublein DM. Burnett JC Jr. Low dose nesiritide and the preservation of renal function in patients with renal dysfunction undergoing cardiopulmonary-bypass surgery: a double-blind placebo-controlled pilot study. Circulation. 2007;116:I134-8. 